\title{
EFFECT OF ROOM TEMPERATURE ON THE QUALITY OF DNA FROM EARPHONE SWAB BY OBSERVING MITOCHONDRIAL DNA [mtDNA] D-LOOP REGION OF 126 bp (HVS II, nt 34- 159) AND 143 bp (HVS I, nt 16268-16410)
}

\author{
Ahmad Yudianto ${ }^{1,2}$, Nola Margaret ${ }^{1}$ \\ ${ }^{1}$ Department of Forensic Medicine \& Medicolegal, Faculty of Medicine, Airlangga University, \\ ${ }^{2}$ Forensic Science Master Program, School of Postgraduate Studies, Airlangga University, Surabaya, Indonesia
}

\begin{abstract}
ABSTRAK
Benda-benda yang terdapat di dalam Tempat Kejadian Perkara maupun sekitarnya mempunyai makna dalam pemeriksaan identifikasi forensik. Spesimen yang banyak dipakai dalam pemeriksaan untuk identifikasi adalah bercak darah/darah, bercak semen, vaginal swab, buccal swab dan tulang, termasuk benda yang sering digunakan pelaku/korban terakhir kalinya. Misal, alat bantu dengar handphone (headset/earphone). Dalam penggunaannya earphone menempel pada kulit telinga bagian luar sehingga diduga ada serumen yang menempel pada alat tersebut. Salah satu faktor yang dapat mempengaruhi kualitas DNA adalah lama paparan. Sampai saat ini di Indonesia efek lama paparan suhu kamar terhadap kualitas DNA pada bahan DNA swab earphone melalui analisis DNA belum banyak diketahui. Jenis penelitian adalah eksperimental laboratoris. Earphone yang telah digunakan dipaparkan pada suhu kamar dalam waktu 1, 7, 14 dan 20 hari. Hasil penelitian ini menunjukkan bahwa efek lingkungan, yakni lama paparan, berpengaruh terhadap penurunan kadar DNA secara cukup signifikan dari hari ke 1 sampai ke 20. Deteksi visualisasi hasil PCR mtDNA D-Loop HVS I 143bp nt: 1626816410 menunjukkan hasil deteksi positif (+) hanya pada paparan suhu kamar hari ke 1 [4 sampel/66,67\%] dan hari ke 7.[ 3 sampel/50\%]. Visualisasi hasil PCR mtDNA D-Loop HVS II 126bp nt: 34 -159 dilakukan pada paparan suhu kamar hari ke 1 [ 2 sampel/33,37\%] dan hari ke 7 [6 sampel/100\%]. Simpulan, lama waktu paparan suhu kamar berpengaruh terhadap kualitas DNA dari bahan swab earphone. Penurunan kadar DNA swab earphone menunjukkan nilai signifikansi $(p<0.005)$ terhadap pengaruh lama waktu paparan suhu kamar. (FMI 2017;53:86-93)
\end{abstract}

Kata kunci: swab earphone, kualitas DNA, DNA mitokondria

\begin{abstract}
The objects contained in crime scene and its surroundings have significance in the examination of forensic identification. The most commonly used specimens in the examination for identification are blood/blood spots, semen patches, vaginal swabs, buccal swabs and bones, including items often used by the perpetrator/victim the last time. For example, a mobile phone hearing aid (headset/earphone). In the use of earphones attached to the outer ear skin so it is suspected there is a serumen attached to the tool. One factor that can affect the quality of DNA is the prolonged exposure. Until now in Indonesia the effect of long exposure to room temperature on the quality of DNA on the DNA material of earphone swabs through DNA analysis has not been widely known. The type of study was laboratory experimental. Used earphones are exposed at room temperature within 1, 7, 14 and 20 days. The results of this study indicate that the environmental effect, ie the duration of exposure, affects the decrease in DNA content significantly from day 1 to 20. Detection of PCR mtDNA D-Loop HVS I visualization results 143 bp nt: 1626816410 shows positive detection results (+) Only at day 1 exposure to room temperature [4 sample/66,67\%] and day 7 [3 sample/50\%]. Visualization of PCR results mtDNA D-Loop HVS II 126bp nt: 34 -159 was performed on day 1 day room exposure [2 sample/33,37\%] and day 7 [6 sample/100\%]. Conclusion, the duration of exposure to room temperature affect the quality of DNA from earpiece swab material. Decreased levels of earphones DNA swabs showed a significance value $(p<0.005)$ against the effect of long time exposure to room temperature. (FMI 2017;53:86-93)
\end{abstract}

Keywords: earphone swab, DNA quality, mitochondrial DNA

Correspondence: Ahmad Yudianto, Department of Forensic Medicine \& Medicolegal, Faculty of Medicine, Airlangga University, Jalan Prof Dr Moestopo 47, Surabaya 60131, Indonesia. E-mail: yudi4n6sby@yahoo.co.id

\section{INTRODUCTION}

Personal identification through DNA analysis is an accurate diagnostic tool in the field of forensics (Yudianto 2010). The advantage of DNA analysis is the stability of somatic cells. DNA images of blood, sperm, hair, organs and so forth are identical so it is suitable for use as an identification material (Notosoehardjo 1999). At the scene of the case will get trace evidence of biology and objects/tools that are often used perpe-trators or victims for the last time. One of them is a hearing aid mobile phone that is now again rife the headset or earphone. This tool is widely used by many people. Headset/earphone is an audio electronics device used in 
hearing the sound of mobile phone or MP3. In the use of earphones attached to the outer ear skin so it is suspected that there are serumen attached to the tool. In Japan has done research on it. Seo et al (2002) identifies forensics through the serum material attached to the earphone used by the offender. Kusuma and Sosiawan (2004) analyzed the effectiveness of serum swab as an alternative material of DNA paternity examination, and Yudianto (2015) used mitochondrial DNA analysis of earphones swab as an alternative identification material. Thus, earphones/headsets have meaning in forensic identification.

Often, in the process of examination, the material or specimen of DNA examination is not as expected. For example, the specimen is not fresh or fresh for DNA analysis or called degraded DNA (Notosoehardjo 1999, Butler 2003, Yudianto 2010). One of the alternatives pursued at this time by forensic DNA experts is through the use of mini-primers sets, ie through STR assays reduction methods, on examination of core DNA loci, as well as by reducing the size of the area Hypervariable region [HVS] 1 or 2 in mitochondrial DNA used as a product of amplification (Gabriel et al 2001).

In forensic identification, mitochondrial DNA (mtDNA) is used to determine kinship, thus accelerating the identification process, especially in cases of massive disaster with large numbers of victims. In mtDNA there is an area that does not encode a protein called D-Loop on the nucleotide number (nt) $16.024-576$. This area is also called the control region, because it is a segment containing the origin of replication elements, the initiation of transcription and regulators.

This study used a long time of exposure as a benchmark ie days $1,7,14$ and 20 . So far the effect of exposure to room temperature on the quality of DNA swab earphone for use as an identification material through mitochondrial DNA analysis is still not widely known. The purpose of this study was to analyze the effect of room temperature exposure on the quality of DNA swab earphones through mitochondrial DNA analysis.

\section{MATERIALS AND METHODS}

This type of research is experimental laboratory with time series research design. The study sample was the
DNA of the earphone swabs taken from the respondents who had agreed and signed the informed consent. From the calculation results known the number of samples required 30 samples of earphones. The research material is the earphone swab. Materials for DNA extraction: Reagent DNAzol, $100 \%$ \& $70 \%$ ethanol solution. Material for PCR: PCR Mix (12.5 ul) consisting of dNTP (ATP, CTP, TTP GTP), $\mathrm{MgCl} 2$ and Taq Polymerase, DW sigma (Nuclease Free water), mtDNA primary 143 bp (HVS I, nt 16268-16410) (Edson et al 2004) 5 'CAC TAG GATACCA ACAAACC 3' \& 5 'GAGGATGGTCAA GGGAC 3', mtDNA 126 bp (HVS II, nt 34-159) (AFDIL, primer Gabriel et al 2001) 5 'GGG AGC TCT CCA TGC ATT TGG TA 3' \& 5 'AAA TAA TAG GAT GAG GGA ATC 3'

\section{RESULTS}

\section{Analysis of the effect of exposure time of room temperature on dna level of earphone swab material}

This research begins with the exposure of samples, namely the exposure of room temperature on the earphone. The temperature and exposure time in this study were 29.5 degrees $\mathrm{C}-30 \mathrm{deg} \mathrm{C}$ in $0.1,7,14$ and 20 days, respectively. Then proceed with sample DNA extraction with DNAzol method. The DNA sampling result was followed by measurement of DNA and DNA purity of the sample by using UV-Visible Spectrophotometer. The mean measurements of DNA measurements for the study sample can be seen in Table 1 .

Table 1. The isolated DNA content of the earpiece swab material

\begin{tabular}{lc}
\hline \multicolumn{1}{c}{ Samples } & $\begin{array}{c}\text { Mean level } \\
(\mathrm{x} \pm \mathrm{SD})(\mu \mathrm{g} / \mathrm{ml})\end{array}$ \\
\hline Day 0 & $152.89 \pm 85.71$ \\
Day 1 & $11.19 \pm 5.58$ \\
Day 7 & $2.15 \pm 0.81$ \\
Day 14 & $0.93 \pm 0.79$ \\
Day 20 & $0.16 \pm 0.42$ \\
\hline
\end{tabular}

Table 1 shows a decrease in the mean DNA content of the earpiece swab material. The longer the exposure time of room temperature, the decreasing the DNA content of the earphone swab material (Fig. 1). 


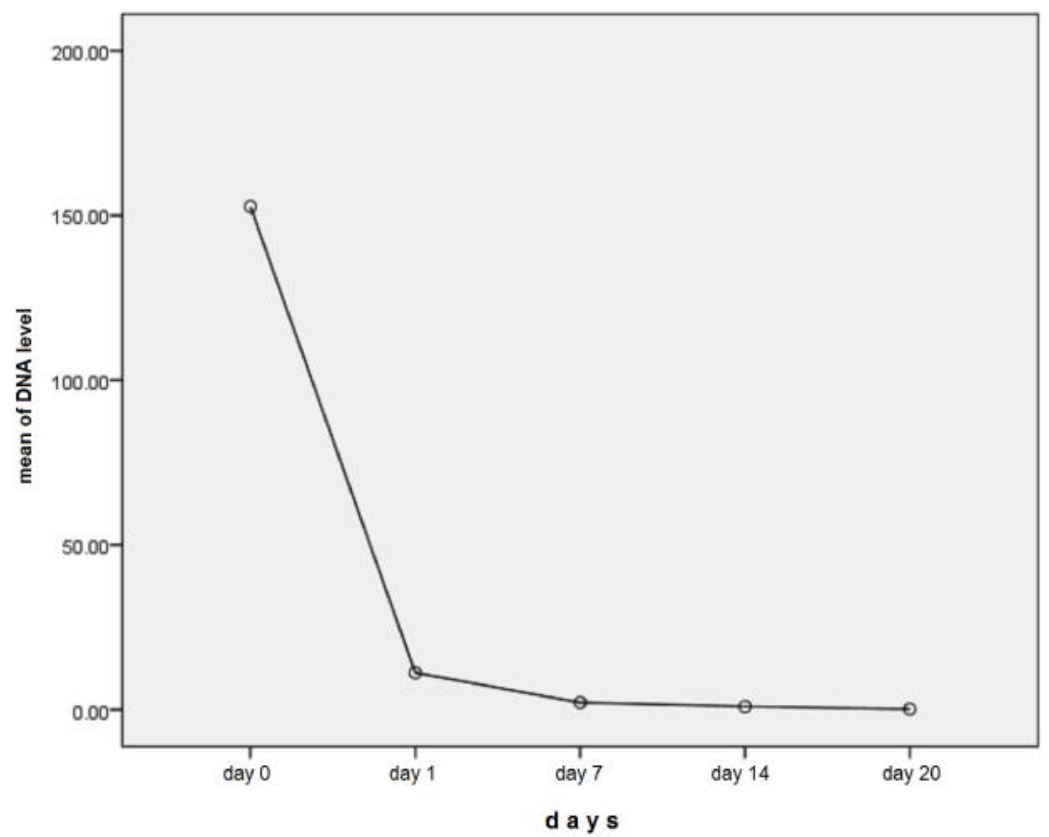

Fig. 1. Effect of long exposure to DNA level of earphone swab.

The result of statistical test of this study shows that there is influence of the exposure time of the room temperature to the decrease of DNA swab earphone (sig. (P): 0.000, sig. $\mathrm{P}<0,05)$.

\section{The result of Polymerase Chain Reaction (PCR) amplification}

The Polymerase Chain Reaction (PCR) amplification process begins with DNA template preparation through the cell lysis process of the earphone swab using an extraction kit (DNAzol). The results of DNA extraction/ isolation was able to produce cell lysates in the form of DNA that is ready to be used as a PCR template. The PCR process uses a primer in the Hipervariable region (HVS II D-Loop 126 bp (nt 59-134) and HVS I D-Loop 143 bp (nt 16268-16410), as shown in Fig. 2.

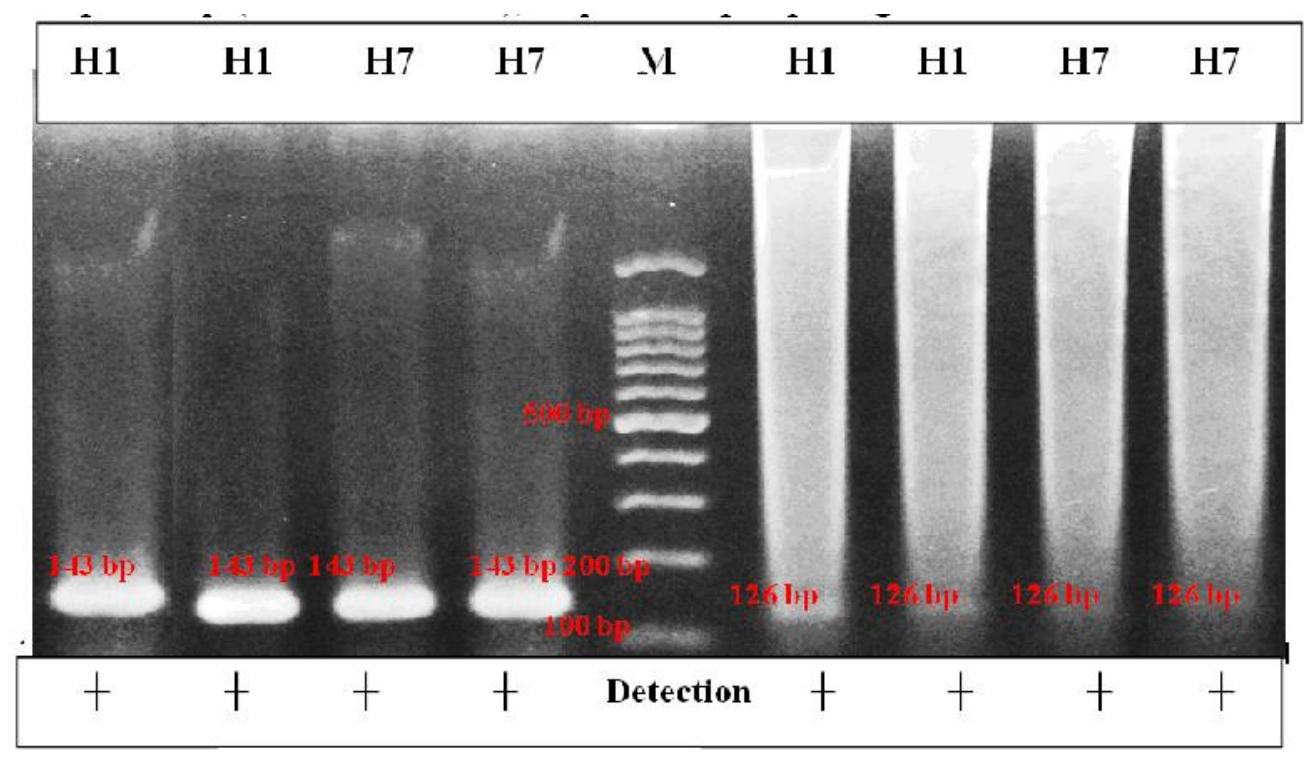

Fig. 2. Result of visualization result of PCR 134 bp \& 126 bp sample of earphone swab, (M) marker, (H1, H7): day 1 and 7 sample. 


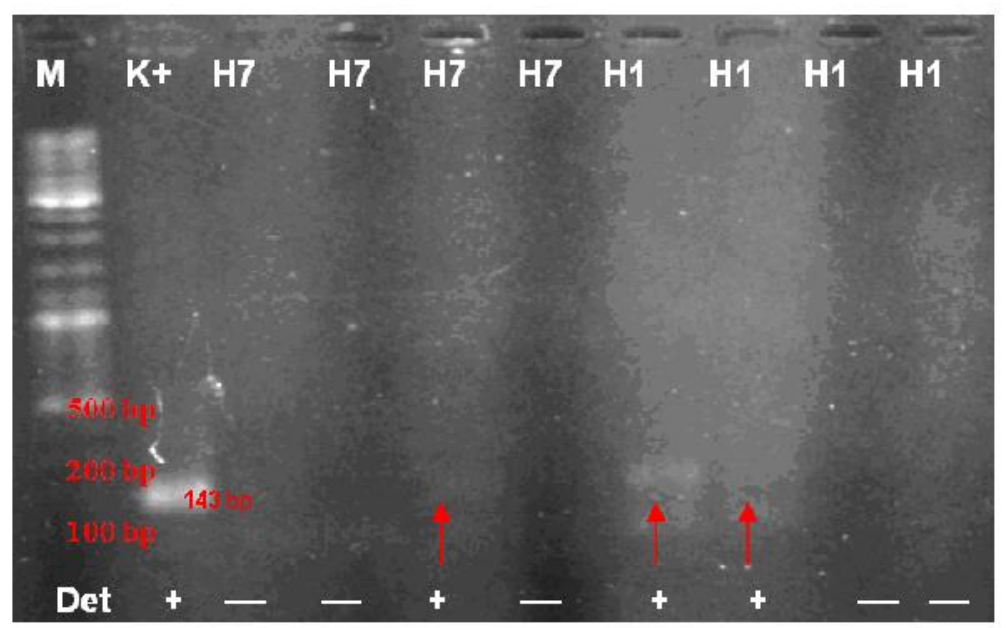

Fig. 3. Visualization of PCR results 143 bp bp sample swab earphone, (M) marker, (H1, H7): day 1 and 7 samples.

Fig. 2 shows all samples days 1 and 7 can still positive detection $(+)$, although on a visualization of $126 \mathrm{bp} 7$ days the two samples showed a vague ribbon. Fig. 3 is a visualization of PCR results in mitochondrial amplicon product DNA $143 \mathrm{bp}$ with electrophoresis using 2\% agarose gel in the sample. In Fig. 3 all 1st day samples showed 2 positive detection samples [ $[+]$ faint band/band and 2 negative detection samples [-] while 7th day samples showed 3 samples of no band/band or negative detection [-]. Only 1 sample with positive detection [+] ribbon/band is cryptic. Visualization of PCR results in mitochondrial amplicon product DNA $143 \mathrm{bp}$ with electrophoresis using 2\% agarose gel is shown in Fig. 4. Fig. 4 shows samples of days 14 and 20 at 143 bp (HVS I D-Loop nt 16268 - 16410). The PCR results were analyzed by agarose gel electrophoresis $2 \%(\mathrm{w} / \mathrm{v})$. The visualization results show all day samples 14 and 20 show no band/band or negative detection [-]. Next, Fig. 5 shows the visualization of PCR results in mitochondrial DNA amplicon product 126 bp with electrophoresis using agarose gel $2 \%$. Fig. 5 shows all day samples to 14 and 20 showing no band/band or negative detection [-], while day 7 still shows band/band or positive detection $[+]$. Table 2 shows the results of detection of the effect of room temperature exposure on mitochondrial DNA of earphones swabs through D-Loop HVS I 143 bp nt: 16268 - 16410 and D-Loop HVS II 126 bp nt: 34 - 159 .

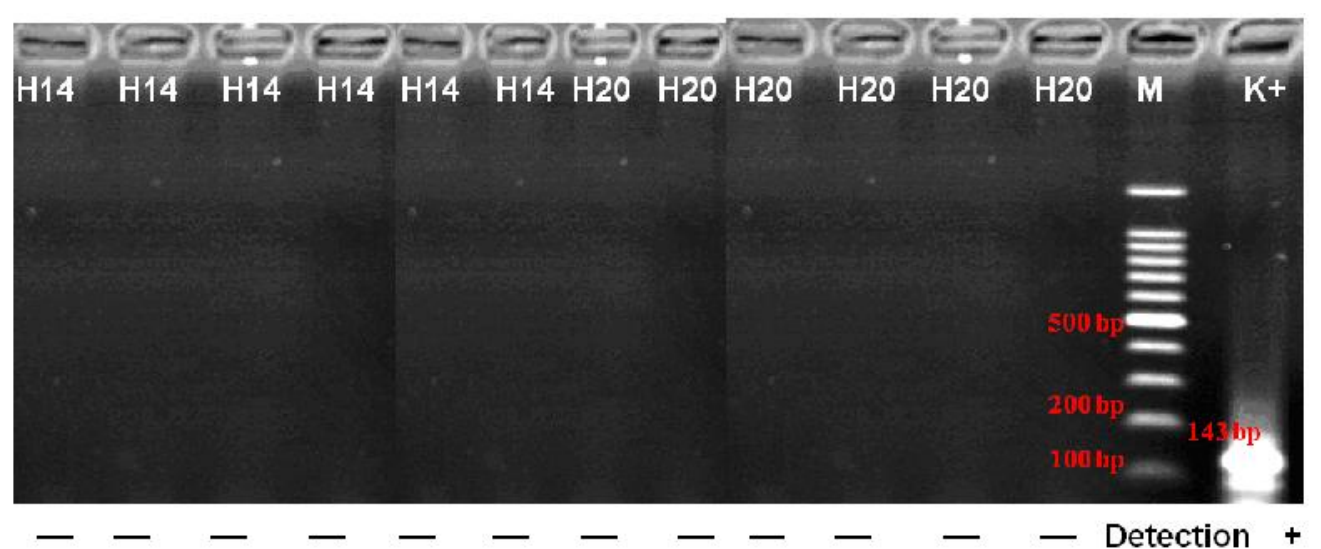

Fig. 4. Visualization of PCR results 143 bp sample of earphone swab, (M) marker, (H14, H20): samples days 14 and 20. 


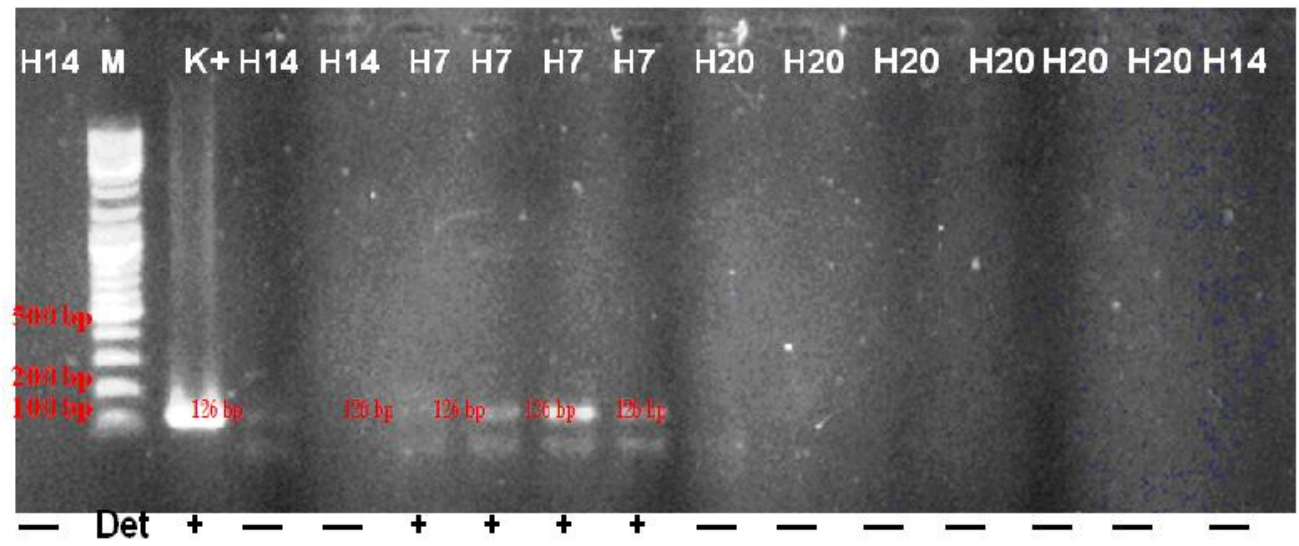

Fig. 5. Visualization of PCR result 126 bp sample of earphone swab, (M) marker, (H7, H14, H20): 7th, 14th and 20th day samples

Table 2. Effect of room temperature exposure on mitochondrial DNA of earphones swab, detection on D-Loop HVS I 143 bp nt: 16268 - 16410 and D-Loop HVS II 126 bp nt: 34 - 159.

\begin{tabular}{llrlll}
\hline \multirow{2}{*}{ Samples } & \multicolumn{2}{c}{ HVS I 143 bp nt : } & \multicolumn{2}{c}{ HVS II 126 bp nt : $34-$} \\
\cline { 2 - 5 } & Detected & Undetected & Detected & Undetected \\
\hline Day 1 & 4 & $2[33.37 \%]$ & 2 & $4[66,67 \%]$ \\
Day 7 & $3[50 \%]$ & $3[50 \%]$ & $6[100 \%]$ & $0[0 \%]$ \\
Day 14 & $0[0 \%]$ & $6\{100 \%\}$ & $0[0 \%]$ & $6[100 \%]$ \\
Day 20 & $0[0 \%]$ & $6[100 \%]$ & $0[0 \%]$ & $6[100 \%]$ \\
\hline
\end{tabular}

Table 2 shows, from exposure to room temperature on days 14 and 20 all of the earphone swab samples were undetectable in the D-Loop HVS I area 143 bp nt: 16268 - 16410 and D-Loop HVS II 126bp nt: $34-159$. On the 1st day, $66.67 \%$ [4 samples] were still detected on D-Loop HVS I 143bp nt: 1626816410 and 33.37\% [2 samples] detected on D-Loop HVS II 126 bp nt: 34 159. While on day 7, 50\% [3 samples] were dropped on D-Loop HVS I 143bp nt: $16268-16410$ and 100\% [6 samples] were detected on D-Loop HVS II 126 bp nt: $34-159$.

Examination of the effect of room temperature exposure through sequencing analysis was performed on several samples which still showed positive detectable results [+]. Sequencing PCR fragment of mitochondrial DNA area D-loop HVS I 143 bp nt: 16268 - 16410 and DLoop HVS II 126bp nt: 34 -159 from earphone swab sample done by Dideoksi Sanger method using Automatic DNA Sequencer based on Dye Terminator Labeling method. Sequencing fragments of PCR results are done by using fragments of the amplified results directly without going through the cloning process. The process is called direct sequencing. This method is used because the process is fast and the result is the dominant nucleotide sequence of PCR amplified DNA. To deter- mine the nucleotide sequence of PCR products measuring $126 \mathrm{bp}$ and $143 \mathrm{bp}$ in the sequencing reaction is used M1 (forward) primer. This study has succeeded in determining the nucleotide sequence of the mtDNA D-Loop region of the sample as shown in Fig. 6.

1st_BASE_2345711_20_143_143.ab1 for day I NNNNNNNNGGNNNNNNNNNNNNNNANNNNGC ATNAACCGNCAGAGCACATTAGGGGCAGACCA NNCTCGCCGCNGNANACGGGNCNCCCGGGGAG ACCAAAGNANCCCGNCGAGCCGGCANCTGNTG AGTCACGACCCGAGAGGNGTGACGNCAGCCTG GGN

>1st_BASE_397247_mtDNA_126bp1.ab1 for day I GTNGNNNTNNNNTNCTCCTTNGNNGTCCCCCGG CGCGCCCCCCTCAAGNNNNNNCTACTNGNCCTG AATTNATTACNGCCNCCTNNTCNCNTGANTNCT GCTNCNNNANGNNNNNGCANNNNNNNNNACG NNNNNNGNNNNNGTNNANNNNNNNNNNNNN NNNNNNCNTAGTCANNNGATNGNTNCTACNNN ATNNNN

Fig. 6. The nucleotide sequence of the D-Loop mtDNA region of the sample in this study. 
The above sequence results show that DNA from the earpiece of mdDNA amplicon product $126 \mathrm{bp}$ and $143 \mathrm{bp}$ on the 1 st day has nucleotide damage characterized by the letter ' $\mathrm{N}$ '

\section{DISCUSSION}

\section{Analysis of the effect of exposure to room temperature on DNA content of earphones swab material}

This study obtained a purity value in the range between $0.00-1.80$ so that the purity of DNA has obtained a good value (value 0.00 indicates the absence of DNA in the sample). The mean DNA content in this study was $23.18 \pm 57.58 \mathrm{ng} / \mu \mathrm{l}$, where a value of 0.00 indicated no DNA in the sample. DNA levels are an important factor in the examination of DNA analysis especially for successful amplification of DNA samples. DNA integrity is very important in forensic DNA testing. This means that although DNA examination is obtained relatively high, if DNA has been fragmented or degra-ded, high levels of DNA become less significant.

The amount of DNA required in DNA analysis varies depending on the need and type of examination. In addition to depending on the levels of DNA, also required adequate DNA quality. The DNA used should be in the least degraded conditions (Butler 2003).

The results of DNA measurement in this study showed a tendency of decreasing DNA content in earphone swab material on the duration of exposure to room temperature. To ascertain how far the influence of the duration of exposure of room temperature to the level of DNA in the sample of this study then performed some statistical tests

The result of statistical test with Kruskall Wallis test and t-test on the DNA content of earphone swabs showed that there was significant effect on the duration of exposure of room temperature (value obtained significance: $0.000, p<0.05$ ). Result of $t$ test on data of DNA value of earphone swab shows significant value: 0.002 , limit of significance $p<0,05$. Thus, there was a significant difference in DNA levels in all prolonged exposure times.

In addition to the DNA content of samples, DNA-based Polymerase Chain Reaction (PCR) testing also requires adequate DNA quality. The DNA used in the analysis should be in a condition that has not been degraded. If the DNA is severely degraded, the primer can not be attached or annealed to the target DNA to be duplicated (Muladno 2002, Yuwono 2006). According to Muladno
(2002), to obtain adequate visualization results requires adequate DNA purity and adequate DNA levels, so that DNA can be used as a checking material, including identification and paternity tests. DNA degradation of exogenous factors is divided into 2 types (Chen $\mathrm{L}$, et al 2000, Yudianto 2009). Type I, DNA is degraded by a relatively long time factor, where DNA damage is often caused by chemical processes and usually the process is slow. Type II, DNA is rapidly degraded due to moisture, sunlight and even extreme high temperatures

In the results of this study, the environmental effects, ie temperature and duration of exposure, affect the measurement of DNA content contained. This is evident from the results of measurements of DNA levels through U.V Spectrophotometry which showed a significant decrease in sample DNA content. However, the decrease in levels is not an obstacle to DNA typing using the PCR method (Notosoehardjo 1999, Butler 2003).

DNA examination by PCR method requires adequate DNA quality. According to Yuwono (2006), the success of PCR depends on several factors, namely deoxyribonucleotide triphosphate (dNTP), primary oligonucleotides, molded DNA, buffer solution, reaction cycle, enzyme used and other technical and non techni-cal factors, eg contamination. DNA quality is consider-ed sufficient when DNA analysis indicates that the DNA used is in good condition and, if degraded, this degradation should be as minimal as possible. If the DNA is in severe degraded condition, the primer can not be attached or anealled to the target DNA to be duplicated. Therefore, good DNA quality is a fundamental prerequisite for successful overall PCR reactons. According to Chung (2004) PCR sensitivity is a function of the number of cycles and levels and integrity of DNA.

\section{Analysis of Polymerase Chain Reaction (PCR) amplification results}

Visualization of Polymerase Chian Reaction (PCR) results were analyzed descriptively by looking at the presence of band images according to PCR product size. This research shows at exposure of room temperature of day 1 and 7, which still can be detected positive [+], seen band through mtDNA D-Loop HVS I 143 bp nt: 16268 - 16410 ie $66,67 \%$ [4 sample] day to I, $50 \%$ [3 samples] day 7, while at day 7: positive detected [+] on mtDNA D-Loop HVS II 126 bp nt: 34 - 159: 33.37\% [3 samples] day I, $100 \%$ [6 samples] day 7 , as well as samples on days 14 and 20 show undetected (not visible band/band) via mtDNA D-Loop HVS I 143 bp nt: 16268 - 16410 and D-Loop HVS II 126 Bp nt: 34 -159. 
Visualization of PCR results in these samples was undetectable because of their DNA quality. DNA quality includes DNA levels, DNA purity and DNA conditions (degradation). Level of DNA in this research on day 14 mean $0,93 \pm 0,79 \mu \mathrm{g} / \mathrm{ml}$ and day 20 mean $0,16 \pm 0,42 \mu \mathrm{g} / \mathrm{ml}$ so enough once.

Examination through DNA analysis by PCR method requires adequate DNA quality. The success of PCR according to Yuwono (2006) depends on several factors, namely deoxyribonucleotide triphosphate (dNTP), primary oligonucleotide, molded DNA, buffer solution, reaction cycle, enzyme used and other technical and non technical factors, such as contamination.

DNA degradation is one of the causes of DNA detection failure in DNA analysis by PCR method in this study. This is in line with what was suggested by Bartlett \& Stirling (2003) and Yudianto (2010) on several possible causes of DNA detection failure, such as minimal target DNA count, DNA degradation so that primers can not stick, lack of DNA polymerase and PCR cycles, And the presence of PCR inhibitors.

The failure of the amplification process is indicated by the absence of bands on the electrophoresis results. This can be anticipated by the use of PCR master mix, which contains $\mathrm{Mg} 2+$, DNA taq Polymerase, dNTP in amounts tailored to the optimum PCR reaction requirements and has proven reliability in current PCR, whereas less cycle Sufficient in PCR reactions, is anticipated by PCR optimization on the primers used (Yudianto 2010).

Insufficient DNA polymerase and PCR cycles can be controlled in detection failure by using the PCR master mix. PCR master mix has $\mathrm{Mg} 2+$ content, DNA tag polymerase, dNTP in amounts tailored to optimum reaction requirements. Concentration of $\mathrm{Mg} 2+$ which is about 1.5-4 mM, excess concentration of $\mathrm{Mg} 2+$ cause non-specific reaction with smear on electrophoresis. Conversely, inadequate $\mathrm{Mg} 2$ + will cause no amplified product or no band/band in the electrophoresis results.

If the amount of enzyme taq polymerase is excessive, there will be a smear (non specific reaction) formation in the electrophoresis picture. Conversely, if it is lacking, the amplification efficiency will be disrupted and give no picture of the band. Difficult form of PCR inhibitor, ie EDTA used in the process of sample decalcification, can be avoided by using ethanol as precipitation in DNA extraction/isolation. Ethanol is a potential material that separates DNA from other components during DNA extraction (Yudianto 2010).
Some results in this study indicate a failure of detection in the form of DNA amplification failure with PCR. This failure can be due to degradation or damaged DNA due to the effects of long time exposure to room temperature. The attachment attached to the earphone contains an external ear canal cell that is detached. These epithelial cells are unprotected so that they are directly exposed to external factors that cause faster DNA degradation.

According to Melcher (2000) external DNA damage caused by exposure, eg, X-rays, chemical agents, spontaneous instability, or by very high temperatures (extreme temperatures), will lead to many types of damage, eg, DNA strand damage Double strand or single strand), base damage (DNA base damage), sugar damage, even the occurrence of DNA-DNA crosslinks and DNA-protein crosslinks. These environmental factors cause degraded DNA. This degradation can be sooner or later, depending on the factors that affect and the time of exposure.

In this research, earpiece swab material can still be used as DNA analysis material in mtDNA examination of room temperature exposure (28 degrees $\mathrm{C}-31 \mathrm{deg} \mathrm{C}$ ) that is maximal on day 7. The findings in this research are expected to be applied in identification so that it can be considered In accelerating the identification process especially in the event of mass disaster or other criminal cases, especially in the crime scene with little trace evidence.

\section{Sequencing Results Analysis}

Examination of the effects of exposure to room temperature through sequencing analysis conducted on several samples still showed positive results detected [+]. Samples that are still worth was sampled on days 1 and 7, while the sample at day 14 and the 20 is no longer feasible because it shows there is no [detection ]. PCR fragments sequenced mitochondrial DNA region D-loop HVS I 143 bp nt: 16268-16410 and D-Loop HVS II 126bp nt: 34 -159 of earphones swab samples conducted by Sanger dideoxy method using Automatic DNA sequencer based on the method Dye Terminator Labeling .

Results of DNA sequencing readings after exposure to room temperature found the existence of the symbol ' $\mathrm{N}$ '. The symbol "N" according to International Union of Pure and Applied Chemistry (IUPAC) is a way to mention the existence of ambiguities. 


\section{CONCLUSION}

The duration of exposure to room temperature affects the DNA quality of the earpiece swab material. Decreased levels of earphones DNA swabs showed significance value $(p<0.005)$ against the influence of long time exposure to room temperature. Visualization of results of PCR detection of mtDNA D-loop HVS I 143bp nt: 1626816410 which shows the detection result of the positive $(+)$ only on the room temperature exposure to 1 [ 4 samples/66.67\%] and day 7 [3 samples/ $50 \%$ ]. Visualization of PCR products of mt-DNA Dloop HVS II 126bp nt: $34-159$, which is at room temperature exposure days 1 [2 samples/33.37\%] and day 7 [6 samples/100\%].

\section{REFERENCES}

Bartlett JM, Stirling D (2003). A short history of the polymerase chain reaction. Methods Mol Biol 226, 3-6

Butler JM, Shen Y, McCord BR (2003). The development of reduced size STR amplicons as tools for analysis of degraded DNA. J Forensic Sc 48, 1054-64

Edson SM, Ross JP, Coble MD, et al (2004). Naming the dead-confronting realities of rapid identification of degraded skeletal remains:Forensic Science Rev Vol $16,69-74$

Gabriel MN, Huffine EF, Ryan JH, et al (2001). Improved mtDNA sequence analysis of forensic remains using a "mini-primer" set amplification strategy; J Forensic Sci 46, 247

Kusuma SE, Sosiawan A (2004). Efek temperature ekstrim pada DNA inti dan DNA mitokondria. Preliminary Research, Research Institution of Airlangga University.

Muladno (2002). Seputar teknologi rekayasa genetika. 1st ed. Bogor, Pustaka Wirausaha Muda

Notosoehardjo I (1999). Penentuan Jenis Kelamin berdasarkan Pemeriksaan DNA dan Antropometri tulang. Doctoral Dissertation, Airlangga University, Surabaya.|

Seo Y, Uchiyama T, Matsuda H, et al (2002). Mitochondrial DNA and STR typing of matter adhering to an earphone. Journal of Forensic Sci 47, 605-608

Yudianto A (2009). Sex determinant melalui pemeriksaan DNA rambut manusia. Medical research unit, Airlangga University, Surabaya

Yudianto A (2010). Analisis DNA tulang dan gigi pada lokus short tandem repeat-combined DNA index system (STR-CODIS),Y-Chromosome STRs \& mitochondrial DNA (mtDNA) akibat efek paparan panas suhu tinggi. Dissertation, Airlangga University, Surabaya

Yudianto A, Sispitasari YE, Margaret N (2015). Analisis DNA mitokondria swab earphone sebagai bahan alternative pemeriksaan identifikasi forensic. Penelitian Unggulan Sekolah Pascsarjana, Airlangga University, Surabaya

Yuwono T (2006). Teori dan aplikasi polymerase chain reaction. Yogyakarta, Penerbit Andi 